\title{
Discover the power of light: student research laboratory for optical engineering at ITMO University
}

\section{N. Tolstoba, A. Saitgalina}

N. D. Tolstoba, A. K. Saitgalina, "Discover the power of light: student research laboratory for optical engineering at ITMO University," Proc. SPIE 9946, Optics Education and Outreach IV, 994611 (27 September 2016); doi: 10.1117/12.2237423

EDent: SPIE Optical Engineering + Applications, 2016, San Diego, California, United States 


\title{
Discover the power of light: student research laboratory for optical engineering at ITMO University
}

\author{
Tolstoba N. D., Saitgalina A. K. \\ ITMO University, Kronverksky ave 49, Saint Petersburg, RF, 197101; Dept. Applied \\ and Computer Optics
}

\begin{abstract}
Russia's student training program continues to set new, ever more difficult goals for itself every year. Nowadays, it has three main aims: the first is to train well-educated professionals; the second is to encourage students' research activity; and last but not least is to draw youth into the arena of global education. This latter point has recently become a key purpose for just about every university in the country. Thus, the Student Research Laboratory for Optical Engineering (SRLOE) at ITMO University strives to provide career guidance for students and to promote light and photon technologies. The article below explores the targets of the SRLOE, its great impact to development and progress in this field, and the new vision of technical education. Today we take for granted all those modern things which didn't exist a couple of decades ago, and life proves that there is a multitude of undiscovered and unexplored technologies within this field. Students all over the world aspire to new heights.
\end{abstract}

Key words: optical engineering, new tools, educational trends, workshops, interactive research projects, innovative principles, light technologies, Student Research Laboratory for Optical Engineering.

\section{INTRODUCTION}

The Student Research Laboratory for Optical Engineering takes a novel approach to schooling: students are encouraged to create their own curriculum and research direction rather than being forced to advance according to a narrow template prescribed by current educational trends. This approach, based on innovative principles of development, prepares students to deal with the reality of a fast-paced and constantly-changing world [1].

Student Research Laboratory for Optical Engineering supports a non-classical education approach where students themselves are the most important resource the laboratory possesses. But what exactly does this mean? For every project the laboratory takes on, one of the students imparts his or her knowledge onto a group of those who wish to participate in research work on that project, and they, in turn, are expected to share their own unique views and ideas. Such student teams are called "workshops". It is worth mentioning that a critically-important part of the development of the laboratory is its collaboration with other students' laboratories, such as OLIMP and Fab Lab of the Science and Technology Park of ITMO University [2].

\section{PROJECTS}

Our Student Laboratory is continuously working on new ways of engaging young people in the study of optics and other light-based technologies. Students are asked to solve practical problems in a creative atmosphere. Using their energy and enthusiasm they can widen the borders of their research work until they are contributing to full-fledged scientific projects. Among numerous interactive research projects performed by the students, we can name a lens with sugar coating, a mobile microscope, and an optical stand with prisms and frames designed for demonstrating the fundamentals of optics. The main goal of all these projects to involve young people in an international scientific environment and increase the efficiency of the student's scientific activities in the university through:

- $\quad$ participation in international scientific societies (SPIE, OSA, IEEE and others);

- active involvement in the implementation of joint research projects with leading international universities;

- $\quad$ participate in competitions and grants (fundraising);

- realization of the project of open laboratories for foreign young scientists;

- material incentives for student publications.

Optics Education and Outreach IV, edited by G. Groot Gregory, Proc. of SPIE Vol. 9946, 994611

(c) 2016 SPIE · CCC code: $0277-786 \mathrm{X} / 16 / \$ 18 \cdot$ doi: $10.1117 / 12.2237423$ 
Main tasks:

1. Develop an environment for student international research activities and increasing ITMO University student's

2. Motivation to research activities.

3. Raising young people's publishing activity.

4. Promotion of ITMO University scientific achievements in general, and in particular the achievements of university students and young scientists.

Table 1. Projects of Laboratory

\begin{tabular}{|c|c|}
\hline Description of the project & Task \\
\hline $\begin{array}{l}\text { Optical labyrinth } \\
\text { The interactive, mobile project for the } \\
\text { study of geometric optics. The player's } \\
\text { goal is to guide a light signal, generated by } \\
\text { a laser pointer, around obstacles on the } \\
\text { game field using various prisms, and } \\
\text { ultimately into a photo-detector. }\end{array}$ & $\begin{array}{l}\text { Development of frames for prisms which } \\
\text { design is made taking into account } \\
\text { labyrinth dimensions. }\end{array}$ \\
\hline $\begin{array}{l}\text { Blaster } \\
\text { Two toy weapons supplied with IR- } \\
\text { sources, and two IK- receivers which are } \\
\text { placed on a vest together form the } \\
\text { equipment for a player whose task is to } \\
\text { eliminate the opponent [3]. }\end{array}$ & $\begin{array}{l}\text { Calculation of optical system in order to } \\
\text { form a parallel beam taking into account } \\
\text { the detected optics; hit detection; } \\
\text { development of the case and its further } \\
\text { modernization. }\end{array}$ \\
\hline $\begin{array}{l}\text { Equipment for demonstration } \\
\text { fundamental laws of optics } \\
\text { Camera obscura: series of experiences of } \\
\text { optical phenomena; portable fastening for } \\
\text { telescopic systems. }\end{array}$ & $\begin{array}{l}\text { Evident representation of the } \\
\text { fundamental laws of optics. }\end{array}$ \\
\hline $\begin{array}{l}\text { Sugar lens } \\
\text { Refraction and magnification using } \\
\text { optical material made from caramel. }\end{array}$ & $\begin{array}{l}\text { Achievement minimum cystic, cord and } \\
\text { transparency in the glass. }\end{array}$ \\
\hline $\begin{array}{l}\text { Mobile microscope } \\
\text { The universal device available to all } \\
\text { smartphones and tablets with a possibility } \\
\text { of resolving the microstructure of tissue. }\end{array}$ & $\begin{array}{l}\text { The creation of a fastening for a } \\
\text { magnifying lens connecting it to any } \\
\text { mobile device. }\end{array}$ \\
\hline $\begin{array}{l}\text { Comics about optics } \\
\text { Explanation of basic optics laws and the } \\
\text { phenomena in a comic book format about } \\
\text { Mr. Laytmen. }\end{array}$ & $\begin{array}{l}\text { The choice of materials and subjects for } \\
\text { representation in a graphic format and } \\
\text { the simplification of the presented topics. }\end{array}$ \\
\hline Exhibition of optical effects & $\begin{array}{l}\text { Promoting of optics by means of } \\
\text { demonstration and an explanation of } \\
\text { various optical phenomena, such as } \\
\text { lowercase this word internal reflection, } \\
\text { interference and variability of index of } \\
\text { refraction in the environment. }\end{array}$ \\
\hline
\end{tabular}




\begin{tabular}{|l|l|}
\hline $\begin{array}{l}\text { Glucose meter } \\
\text { A noninvasive procedure for measuring } \\
\text { blood sugar levels. Since the procedure } \\
\text { does not require piercing skin, it is } \\
\text { painless and safer for the user. }\end{array}$ & $\begin{array}{l}\text { Development of a portable glucometer; } \\
\text { development of the principle of its } \\
\text { work. }\end{array}$ \\
\hline $\begin{array}{l}\text { Endoscopy capsule } \\
\text { A single capsule that can be used as a } \\
\text { replacement for an endoscope. }\end{array}$ & $\begin{array}{l}\text { Development of a comfortable device } \\
\text { for endoscopy; calculation of the } \\
\text { optical scheme. }\end{array}$ \\
\hline $\begin{array}{l}\text { Overhead projector } \\
\text { Modernization of electronic projection }\end{array}$ & $\begin{array}{l}\text { Search for an electronic matrix capable } \\
\text { of replacing transparent films; creation } \\
\text { of necessary fastenings; selection of } \\
\text { dimensions and settings for the } \\
\text { projector such that there is no reduction } \\
\text { of a bunch. }\end{array}$ \\
\hline
\end{tabular}
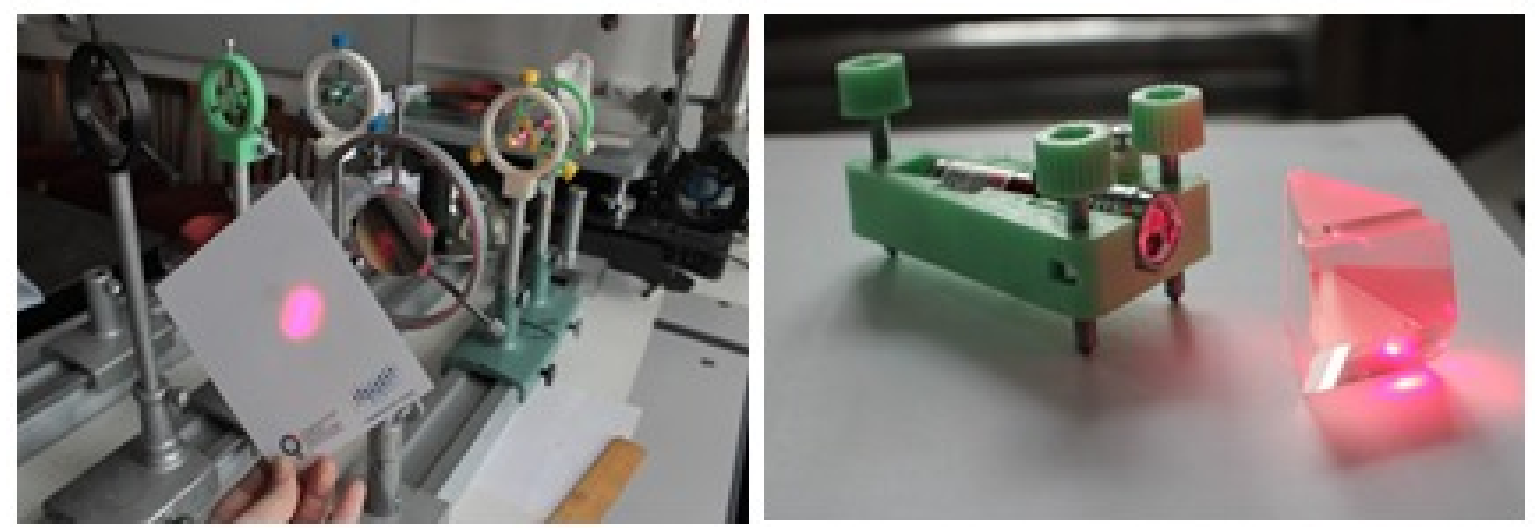

Figure1. Samples of the projects

\section{CONCLUSION}

Our experience with the Laboratory has shown that it is possible to create similar laboratories at other university departments, providing:

- Openness of laboratories for students' initiatives;

- Cooperation between different organizations and laboratories;

- Clear understanding of purpose within the professional sphere;

- Expansion of student skillsets and competencies;

- Increase of employability by profession;

- Increase of level of interest in a focus area;

- Invaluable experience of leading projects and improving management skills.

Drawing students' attention to science and quality independent education is the key purpose of this laboratory. The availability of career guidance and a comfortable space for performing research work all help attract the best people possible to the University, and also help them reach their true scientific and technical potential.

\section{REFERENCES}

1. Tolstoba N.D., Saitgalina A.K., Abdula P.A., Butova D.V. Student research laboratory for optical engineering // Proceedings of SPIE - 2015, Vol. 9793, pp. 97931Y 
2. Dan Curticapean University for Children - The Magic of Light [Text] / Dan Curticapean // Proc. of SPIE Vol. 9666 966604-1/ Offenburg. University of Applied Sciences, Offenburg, Badstr. 24, 77652 Offenburg, Germany, 2009.

3. Charles H. Townes: How the Laser Happened, Adventures of a Scientist - Oxford University Press, Inc. New York, Oxford 1999, ISBN 0-19-512268-2 